\title{
Biosensor analysis of anti-citrullinated protein/peptide antibody affinity
}

\author{
Giada Rossi ${ }^{a}$, Feliciana Real-Fernández ${ }^{\mathrm{b}}$, Filomena Panza ${ }^{\mathrm{c}}$, Francesca Barbetti $^{\mathrm{b}}$, Federico Pratesi ${ }^{\mathrm{c}}$, \\ Paolo Rovero ${ }^{\mathrm{a}, \mathrm{b}, *}$, Paola Migliorini ${ }^{\mathrm{b}, \mathrm{c}, *}$ \\ ${ }^{a}$ Laboratory of Peptide and Protein Chemistry and Biology, Department of NeuroFarBa, Division of Pharmaceutical Sciences and Nutraceutic, University of Florence, \\ 50019 Florence, Italy \\ ${ }^{\mathrm{b}}$ Toscana Biomarkers, 53100 Siena, Italy \\ ${ }^{\mathrm{c}}$ Clinical Immunology and Allergy Unit, Department of Clinical and Experimental Medicine, University of Pisa, 56126 Pisa, Italy
}

\section{A R T I C L E I N F O}

Article history:

Received 4 July 2014

Received in revised form 29 July 2014

Accepted 31 July 2014

Available online $\mathrm{xxxx}$

\section{Keywords:}

Anti-citrullinated protein/peptide antibodies

Affinity

Surface plasmon resonance

Rheumatoid arthritis

Autoantibodies

\begin{abstract}
A B S T R A C T
Anti-citrullinated protein/peptide antibodies (ACPAs) are detected in rheumatoid arthritis (RA) sera and because of their strict association with the disease are considered marker antibodies, probably endowed with pathogenic potential. Antibody affinity is one of the parameters affecting pathogenicity. Three diagnostic citrullinated peptides-viral citrullinated peptide 1 (VCP1) and VCP2 derived from EpsteinBarr virus (EBV)-encoded proteins and histone citrullinated peptide 1 (HCP1) derived from histone H4-were synthesized as tetrameric multiple antigen peptides and immobilized on sensor chips CM5 type in a Biacore T100 instrument. Specific binding of purified antibodies from RA patients to the three peptides was analyzed by surface plasmon resonance using two arginine-containing sequences as controls. Employing a 1:1 binding model for affinity constant calculation, ACPAs interacted with VCP1 and VCP2 with lower apparent affinity $\left(10^{-6} \mathrm{M}>K_{\mathrm{D}}>10^{-7} \mathrm{M}\right)$ and interacted with HCP1 with higher apparent affinity $\left(K_{\mathrm{D}}=10^{-8} \mathrm{M}\right)$. The results indicate that the binding to citrullinated peptides is characterized by wide differences in affinity, with slower association and faster dissociation rates in the case of antibodies to viral citrullinated peptides as compared with antibodies specific for the histone peptide. This biosensor analysis shows the high cross-reactivity of purified ACPAs that bind other citrullinated peptides besides the one used for purification.
\end{abstract}

(c) 2014 Elsevier Inc. All rights reserved.
Q1 * Corresponding authors. Address: Laboratory of Peptide and Protein Chemistry and Biology, Department of NeuroFarBa, Division of Pharmaceutical Sciences and Nutraceutic, University of Florence, 50019 Florence, Italy (P. Rovero). Address: Clinical Immunology and Allergy Unit, Department of Clinical and Experimental Medicine, University of Pisa, 56126 Pisa, Italy (P. Migliorini).

E-mail addresses: paolo.rovero@unifi.it (P. Rovero), paola.migliorini@med.unipi. it (P. Migliorini)

${ }^{1}$ Abbreviations used: RA, rheumatoid arthritis; ACPA, anti-citrullinated protein/ peptide antibody; VCP, viral citrullinated peptide; EBV, Epstein-Barr virus; ELISA, enzyme-linked immunosorbent assay; CCP, cyclic citrullinated peptide; SPR, surface plasmon resonance; RI, reflective index; HCP, histone citrullinated peptide; MAP, multiple antigen peptide; IgG, immunoglobulin G; PBS, phosphate-buffered saline; NHS, N-hydroxysuccinimide; EDC, 1-ethyl-3-(3-dimethylaminopropyl)-carbodiimide; PDEA, 2-(2-pyridinyldithio)ethaneamine; EPNA, Epstein-Barr nuclear antigen. recently included in the serological criteria for the classification of this disease [2].

ACPAs recognize different self-proteins, such as filaggrin, fibrinogen, vimentin, collagen II, enolase, and histone $\mathrm{H} 4$ [3,4], the arginyl residues of which have been post-translationally transformed into citrullyl residues. We previously showed that also viral citrullinated peptide 1 (VCP1) and VCP2, citrullinated sequences derived from Epstein-Barr virus (EBV)-encoded proteins, are recognized by antibodies of the ACPA family [5,6], thereby adding exogenous citrullinated antigens to the list of ACPA substrates. All of these citrullinated proteins and peptides have been used to set up enzymelinked immunosorbent assays (ELISAs) for ACPA detection in RA diagnosis. The more frequently used assay is cyclic citrullinated peptide (CCP), originally based on cyclic citrullinated sequences derived from filaggrin [7] but in the later versions employing different citrullinated peptides obtained from the screening of a peptide library [1].

The association of ACPAs, measured using any of the abovementioned antigens, with erosive arthritis has suggested a role of the antibodies in inducing inflammation and joint damage. One 
of the possible pathogenic activities of ACPAs is the formation of immune complexes, with consequent release of pro-inflammatory cytokines from monocytes/macrophages mediated by Fc- $\gamma$ RIIa engagement [8]. ACPAs may also induce the release of tumor necrosis factor alpha (TNF- $\alpha$ ) through binding to Grp78, a chaperone protein expressed on monocyte membrane [9]. The affinity of autoantibodies for their target is considered a relevant parameter in determining their pathogenicity.

In the case of anti-glomerular basement membrane (anti-GBM) antibodies, the fulminant nature and the resistance to therapy of nephritis are fully explained by the high affinity of serum autoantibodies that bind the NC1 domain of the $\alpha 3$ chain of type IV collagen [10,11]. Using a biosensor analysis, the anti-collagen IV autoantibodies displayed fast association rates and low dissociation rates, features that may explain both the acute onset of the disease and the resistance to treatment [10].

Anti-(pro)insulin antibodies are frequently produced by patients affected by type I diabetes and also by their relatives, but growing evidence suggests that only those producing highaffinity antibodies develop the disease [12].

Recently, ACPA affinity has been evaluated by elution ELISA and found to be lower than the affinity of immunization-induced antibodies [13,14]. Surface plasmon resonance (SPR)-based optical biosensors have been successfully used to measure the binding and to study the apparent affinity and kinetics of a number of biomolecular interactions, including those of antibodies with cognate antigens $[15,16]$. SPR-based optical biosensors detect changes in reflective index (RI) due to changes in mass on the chip surface following the interaction between the immobilized ligand and the analyte flowing in solution.

SPR-based biosensors have so far been applied to the analysis of monoclonal antibodies derived from synovial B cells of RA patients [17] and to the profiling of ACPA reactivity in RA sera [18]. However, a direct evaluation of ACPA affinity by means of SPR-based biosensors is not yet available. The aim of the current study was to characterize the affinity of ACPA, analyzing the binding of apparent affinity-purified antibodies from RA patients to a panel of citrullinated peptides.

\section{Materials and methods}

All experiments were conducted using a Biacore T100 instrument from GE Healthcare. All solutions and buffers were prepared with MilliQ water obtained from the Sartorius system (arium 611 VF). Sensor chips CM5, a thiol ligand coupling kit, and running buffer HBS-EP+ $10 \times(0.1 \mathrm{~mol} / \mathrm{L} \mathrm{Hepes,} 1.5 \mathrm{~mol} / \mathrm{L} \mathrm{NaCl}, 30 \mathrm{mmol} / \mathrm{L}$ ethylenediaminetetraacetic acid [EDTA], and $0.5 \%[\mathrm{v} / \mathrm{v}] \mathrm{p} 20$ ) were purchased from GE Healthcare. Running buffer was diluted 10 times with MilliQ water at $\mathrm{pH} 7.4$ and filtered daily with a Millipore Express PLUS $0.22-\mu \mathrm{m}$ system. Sodium acetate and sodium hydroxide were purchased from Carlo Erba (Milano, Italy).
The three citrullinated peptides VCP1, VCP2, and histone citrullinated peptide 1 (HCP1) (I-III) and the two non-citrullinated control sequences VArgP2 and HArgP1 (IV and V) were synthesized as tetrameric multiple antigen peptides (MAPs) according to previously described methods [4,5]. Peptide sequences are reported in Table 1.

\section{Purification of anti-peptide antibodies}

Five ACPA-positive RA patients, diagnosed according to the American College of Rheumatology (ACR) classification criteria [2], were enrolled. This study was approved by the ethics committee of the University Hospital of Pisa. After informed consent was obtained, serum samples were stored at $-20^{\circ} \mathrm{C}$. Immunoglobulin $\mathrm{G}$ (IgG) fractions from RA sera containing ACPAs (RA1-RA5) were obtained by precipitation with $50 \%$ saturated ammonium sulfate. The precipitates were dissolved in phosphate buffer $(\mathrm{pH} 7.4)$, dialyzed against phosphate-buffered saline (PBS), and purified by Protein $G$ affinity chromatography.

To isolate anti-peptide antibodies, citrullinated MAPs (I-III) were conjugated to $\mathrm{CNBr}$-activated Sepharose (Sigma-Aldrich, St. Louis, MO, USA) according to standard procedures. Enriched immunoglobulin preparations were applied to the column, and the flowthrough was collected for subsequent analysis. The column was extensively washed with $20 \mathrm{mmol} / \mathrm{L} \mathrm{Na}_{2} \mathrm{HPO}_{4}$ and $150 \mathrm{mmol} / \mathrm{L}$ $\mathrm{NaCl}(\mathrm{pH} 7.2)$, and the antibodies bound to the column were eluted

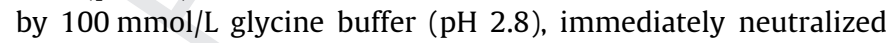
with $50 \mu \mathrm{l}$ of Tris ( $1 \mathrm{~mol} / \mathrm{L}, \mathrm{pH} 8.0$ ), and dialyzed overnight against PBS. The anti-peptide antibody content in the eluates and flowthrough was tested by ELISA. A total of 15 purified anti-peptide antibody fractions were obtained by affinity chromatography from five different RA sera using each of the three citrullinated MAPs.

Peptide immobilization

The five MAPs I to $\mathbf{V}$ were individually immobilized on sensor chips CM5 type. Peptides were covalently linked according to the thiol ligand coupling strategy. This coupling approach introduces reactive disulfide groups into the dextran matrix on the sensor chip, and coupling occurs through thiol-disulfide exchange with thiol groups on the ligand. Immobilization buffers were selected separately for each peptide using the $\mathrm{pH}$ scouting procedure, as described in the instrument protocol, using the following buffers: D-PBS buffer ( $\mathrm{pH} 7.2$ ), sodium acetate buffer $(0.1 \mathrm{mmol} / \mathrm{L}, \mathrm{pH} 4.5$ and 6.0), sodium acetate buffer $(0.5 \mathrm{mmol} / \mathrm{L}, \mathrm{pH} 4.5$ and 5.0$)$, and sodium acetate buffer ( $5 \mathrm{mmol} / \mathrm{L}, \mathrm{pH} 4.5,5.0$ and 6.0). Peptides were solubilized in each buffer at a final concentration of $10 \mu \mathrm{g} / \mathrm{ml}$. The selected buffer and immobilized peptide quantities are reported in Table 1.

For immobilization, sensor chip surface was activated with two injections of $N$-hydroxysuccinimide (NHS, $0.1 \mathrm{~mol} / \mathrm{L}$ ) and 1-ethyl-3-(3-dimethylaminopropyl)-carbodiimide (EDC,

Table 1

Citrullinated peptide and control peptide characteristics.

\begin{tabular}{|c|c|c|c|c|}
\hline Code & Name & Sequence & Immobilization buffer & Immobilized peptide (RU) \\
\hline I & VCP1 & $\begin{array}{l}\text { (Gly Gly Asp Asn His Gly Cit Gly Cit Gly Cit Gly Cit Gly Cit Gly } \\
\text { Gly Gly Cit Pro Gly Ala Pro Gly) }{ }_{4} \text { Lys }_{2} \text { Lys } \beta \text { Ala Cys }\end{array}$ & AcNa $(0.5 \mathrm{mmol} / \mathrm{L}, \mathrm{pH} 4.5)$ & 4080 \\
\hline II & VCP2 & $\begin{array}{l}\text { (Gly Gln Ser Cit Gly Gln Ser Cit Gly Cit Gly Cit Gly Cit Gly } \\
\text { Cit Gly Cit Gly Lys Gly) } \text { Lys }_{2} \text { Lys } \beta \text { Ala Cys }\end{array}$ & AcNa $(0.1 \mathrm{mmol} / \mathrm{L}, \mathrm{pH} 4.5)$ & 4234 \\
\hline III & HCP1 & $\begin{array}{l}\text { (Ala Lys Cit His Cit Lys Val Leu Cit Asp Asn Ile Gln Gly Ile } \\
\text { Thr Lys Pro Ala Ile })_{4} \text { Lys }_{2} \text { Lys } \beta \text { Ala Cys }\end{array}$ & AcNa $(0.1 \mathrm{mmol} / \mathrm{L}, \mathrm{pH} 4.5)$ & 4750 \\
\hline IV & VArgP2 & $\begin{array}{l}\text { (Gly Gln Ser Arg Gly Gln Ser Arg Gly Arg Gly Arg Gly Arg } \\
\text { Gly Arg Gly Arg Gly Lys Gly) } \text { Lys }_{2} \text { Lys } \beta \text { Ala Cys }\end{array}$ & Running buffer (pH 7.4) & 3336 \\
\hline $\mathbf{V}$ & HArgP1 & $\begin{array}{l}\text { (Ala Lys Arg His Arg Lys Val Leu Arg Asp Asn Ile Gln Gly Ile } \\
\text { Thr Lys Pro Ala Ile) })_{4} \text { Lys }_{2} \text { Lys } \beta \text { Ala Cys }\end{array}$ & AcNa $(0.1 \mathrm{mmol} / \mathrm{L}, \mathrm{pH} 5.0)$ & 4282 \\
\hline
\end{tabular}

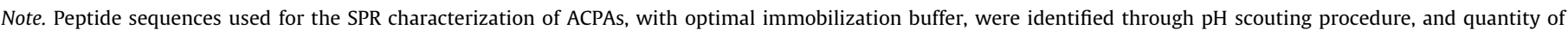
peptide immobilized on chip surface is expressed in resonance units (RU). 
$0.4 \mathrm{~mol} / \mathrm{L})(50: 50)$ for $420 \mathrm{~s}$ at a flow rate of $10 \mu \mathrm{l} / \mathrm{min}$; active disulfide groups were then introduced by twice injecting a solution of $67 \% 120 \mathrm{mmol} / \mathrm{L}$ 2-(2-pyridinyldithio)ethaneamine (PDEA) and $33 \%$ sodium borate $(0.1 \mathrm{~mol} / \mathrm{L}, \mathrm{pH} 8.5)$ for $420 \mathrm{~s}$ at a flow rate of $10 \mu \mathrm{l} / \mathrm{min}$. Each peptide, solubilized in the previously selected immobilization buffer $(10 \mu \mathrm{g} / \mathrm{ml})$, was injected for 420 and $60 \mathrm{~s}$ at a flow rate of $10 \mu \mathrm{l} / \mathrm{min}$. Nonreacted disulfide groups on sensor chip surface were blocked injecting cysteine $(50 \mathrm{mmol} / \mathrm{L})$ and $\mathrm{NaCl}$ $(1 \mathrm{~mol} / \mathrm{L})$ in sodium acetate $(0.1 \mathrm{~mol} / \mathrm{L}, \mathrm{pH} 4.3)$ for $240 \mathrm{~s}$ at a flow rate of $10 \mu \mathrm{l} / \mathrm{min}$. To block free reactive sites formed by NHS/EDC activation, ethanolamine- $\mathrm{HCl}(1 \mathrm{~mol} / \mathrm{L}, \mathrm{pH} 8.5)$ was injected for $420 \mathrm{~s}$ at a flow rate of $10 \mu \mathrm{l} / \mathrm{min}$. Reference channel was activated injecting NHS/EDC (50:50) and PDEA and was directly blocked with cysteine buffer and ethanolamine- $\mathrm{HCl}$.

\section{SPR analyses}

Anti-citrullinated peptide antibody fractions (at different initial concentrations tested by ultraviolet [UV] absorbance at $280 \mathrm{~nm}$ ) were diluted in running buffer to final concentrations of 2000, $1000,500,250,125,62.5$, and $31.25 \mathrm{nmol} / \mathrm{L}$. Diluted samples were injected in duplicate over each immobilized peptide for $120 \mathrm{~s}$ at a flow rate of $30 \mu \mathrm{l} / \mathrm{min}$. Running buffer was then flushed for $200 \mathrm{~s}$ at a flow rate of $30 \mu \mathrm{l} / \mathrm{min}$, and finally the chip surface was regenerated by injecting a glycine solution $(10 \mathrm{mmol} / \mathrm{L}, \mathrm{pH} 2.5)$ for $30 \mathrm{~s}$ and a sodium hydroxide solution $0.1(\mathrm{~mol} / \mathrm{L})$ for $60 \mathrm{~s}$, both at a flow rate of $30 \mu \mathrm{l} / \mathrm{min}$. Control samples were employed to monitor the sensor chip surface stability, demonstrating the reproducibility throughout the duration of the experiments.

\section{Statistical analysis}

Results were elaborated with Biacore Evaluation Software 2.0 and summarized with Biacore T100 Kinetic Summary.

\section{Results}

Peptides I to $\mathbf{V}$ containing Cys in the C terminal were covalently immobilized onto a gold sensor chip following the thiol coupling immobilization strategy to reach immobilization levels reported in Table 1. Anti-peptide antibodies, obtained by peptide affinity chromatography from patient sera, were flowed over each immobilized peptide in an individual cycle of analysis based on the following steps: sample injection (association), washing with running buffer (dissociation), and finally chip surface regeneration. Results were elaborated separately for each sample fitting the experimental values to theoretical kinetic models. Elaborating separately each interaction with Biacore Evaluation Software 2.0, we obtained a high-quality fitting with both the binding 1:1 kinetic model and the bivalent analyte one. According to this latter model, after analyte-ligand interaction at the first site, engagement of the second site does not contribute to SPR response because there is no change in RI or mass over the chip; there is only a sort of rearrangement of the bound analyte. However, a low amount of peptide was immobilized on the sensor chip, thereby limiting the rebinding effect, and in fact the "check data components" option of the software indicated that the interaction with the first binding site was greater than the interaction with the second one. The 1:1 model was validated by three statistical parameters: the residual values between the experimental points and the theoretical ones that are closely distributed along the zero, the chi-square value, and the standard errors that are less than $10 \%$ of the referred parameter value.

Thus, we employed the $1: 1$ binding model to calculate the apparent affinity constant $K_{\mathrm{D}}\left(k_{\mathrm{d}} / k_{\mathrm{a}}\right)$ describing the interactions

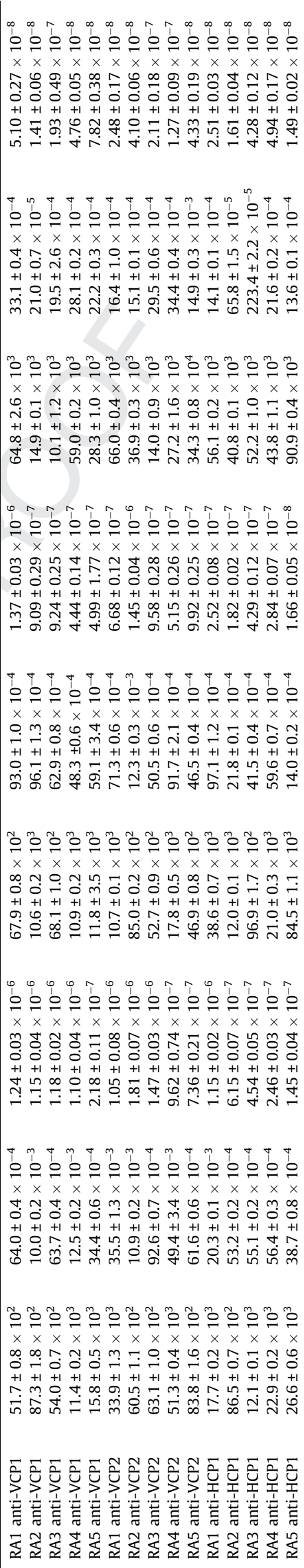


between each purified antibody fraction and each immobilized peptide (Table 2). According to this model, a monovalent analyte molecule binds to a monovalent immobilized ligand as exemplified in this equation:

$\mathrm{Ab}+\mathrm{Lig} \underset{k_{\mathrm{d}}}{\stackrel{k_{\mathrm{a}}}{\rightleftarrows}} \mathrm{Ab}-\mathrm{Lig}$

\section{Analysis of apparent affinity of purified ACPAs}

To summarize the kinetic and affinity results, we used the Biacore T100 Kinetic Summary application and obtained the $k_{\mathrm{a}} / k_{\mathrm{d}}$ plot. 2 This graph provides an overview of kinetic properties for the different interactions studied by plotting the association rate parameter $\left(k_{\mathrm{a}}\right)$ against the dissociation rate parameter $\left(k_{\mathrm{d}}\right)$, both on a logarithmic scale. Apparent affinity constants $K_{\mathrm{D}}$ (calculated as $k_{\mathrm{d}} / k_{\mathrm{a}}$ ratio) are displayed on diagonal lines. Thus, interactions having the same affinity but different kinetics are indicated by points lying on the same diagonal line. In Fig. 1 , we report the $k_{\mathrm{a}} / k_{\mathrm{d}}$ plot for the 15 interactions between each purified antibody fraction and the peptide used for its purification. ACPAs interacted with VCP1 (I) and VCP2 (II) with lower apparent affinity $\left(10^{-6} \mathrm{M}>K_{\mathrm{D}}>10^{-7} \mathrm{M}\right)$ and interacted with HCP1 (III) with higher apparent affinity $\left(K_{\mathrm{D}}=10\right.$ ${ }_{-8}$ M) (Fig. 1).

The kinetics of interaction between purified anti-VCP2 antibodies from patient RA3 and VCP2 (II), characterized by a faster antibody/antigen dissociation, is given as a representative example of high $k_{\mathrm{d}}\left(50.5 \times 10^{-4} \mathrm{~s}^{-1}\right)$ in Fig. 2A. The lack of binding between RA3 anti-VCP2 antibodies and the arginine-containing control peptide (VArgP2) did not allow calculation of kinetic parameters (Fig. 2B). A representative example of low- $k_{\mathrm{d}}$ sensorgrams is given in Fig. 2C, which shows the interaction between anti-HCP1 antibodies from patient RA1 and immobilized peptide HCP1 (III), characterized by a slower antigen/antibody dissociation. The interaction between RA1 anti-HCP1 antibodies and the argininecontaining peptide HArgP1 is given in Fig. 2D.
On the whole, the data reported in Table 2 indicate a high crossreactivity of anti-peptide antibodies. In fact, each antibody fraction, obtained by affinity chromatography on a given peptide, also reacts with the other two peptides. Interactions with HCP1 (III) are mostly characterized by higher apparent affinity, also when involving anti-VCP2 or anti-VCP1 antibodies.

We then tested the binding of anti-VCP2 antibodies to non-citrullinated, arginine-containing peptide VArgP2 and the binding of anti-HCP1 antibodies to non-citrullinated, arginine-containing peptide HArgP1 (Table 3). In four of five cases, no binding signals were detected to VArgP2; patient RA4 displayed the same apparent affinity for both citrulline- and arginine-containing peptides. As far as HArgP1 is concerned, RA3 and RA5 showed no/low binding, RA1 and RA4 had a lower apparent affinity to citrullinated peptide with respect to the arginine-containing sequence, and RA2 bound the arginine-containing peptide with a higher apparent affinity than the citrulline-containing one.

\section{Discussion}

In the current study, we measured with SPR the apparent affinity of ACPAs, analyzing the interaction of IgG anti-peptide antibodies isolated from RA patients' sera with three different diagnostic citrullinated peptides and two non-citrullinated, arginine-containing control peptides. Because peptides contain only one cysteine residue at the $C$ terminal of their sequence, we chose the thiol coupling strategy, which is based on exchange reactions between thiols and active disulfide groups introduced in the dextran matrix. By this approach, we immobilized the peptides in a well-defined orientation on the chip surface, obtaining a better exposition of their antigenic branches.

The results indicate that binding to citrullinated peptides is characterized by wide differences in affinity, with slower association and faster dissociation rates in the case of antibodies to viral citrullinated peptides VCP1 (I) and VCP2 (II), as compared with antibodies specific for the histone peptide HCP1 (III). These results

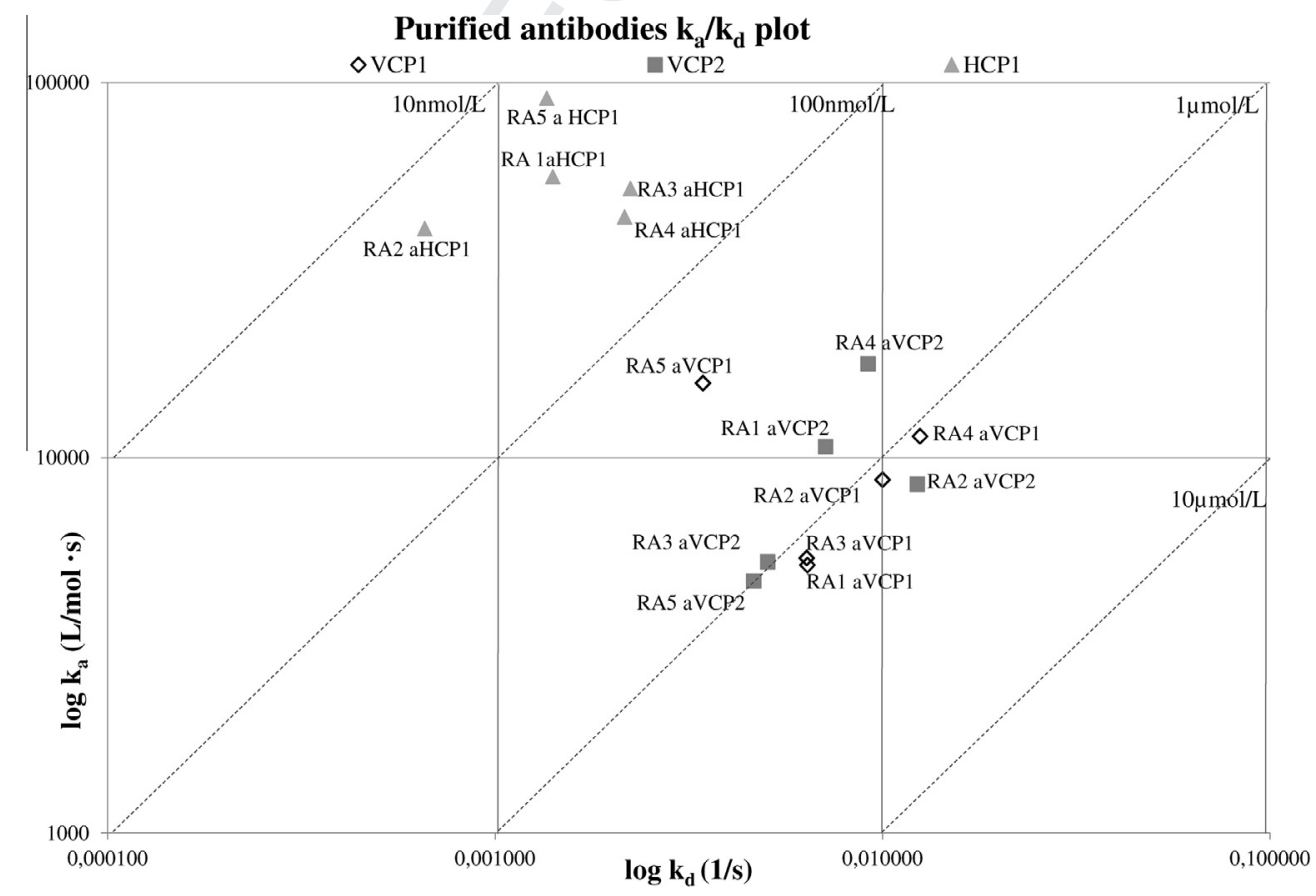

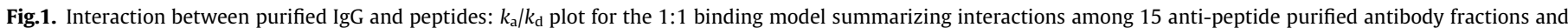

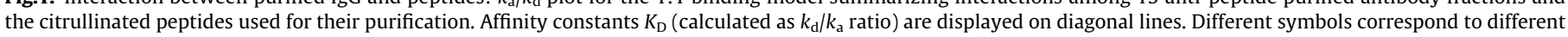
immobilized peptides $(\diamond, \mathrm{VCP} 1 ; \mathbf{\square}, \mathrm{VCP} 2 ; \mathbf{\Lambda}, \mathrm{HCP} 1)$. 

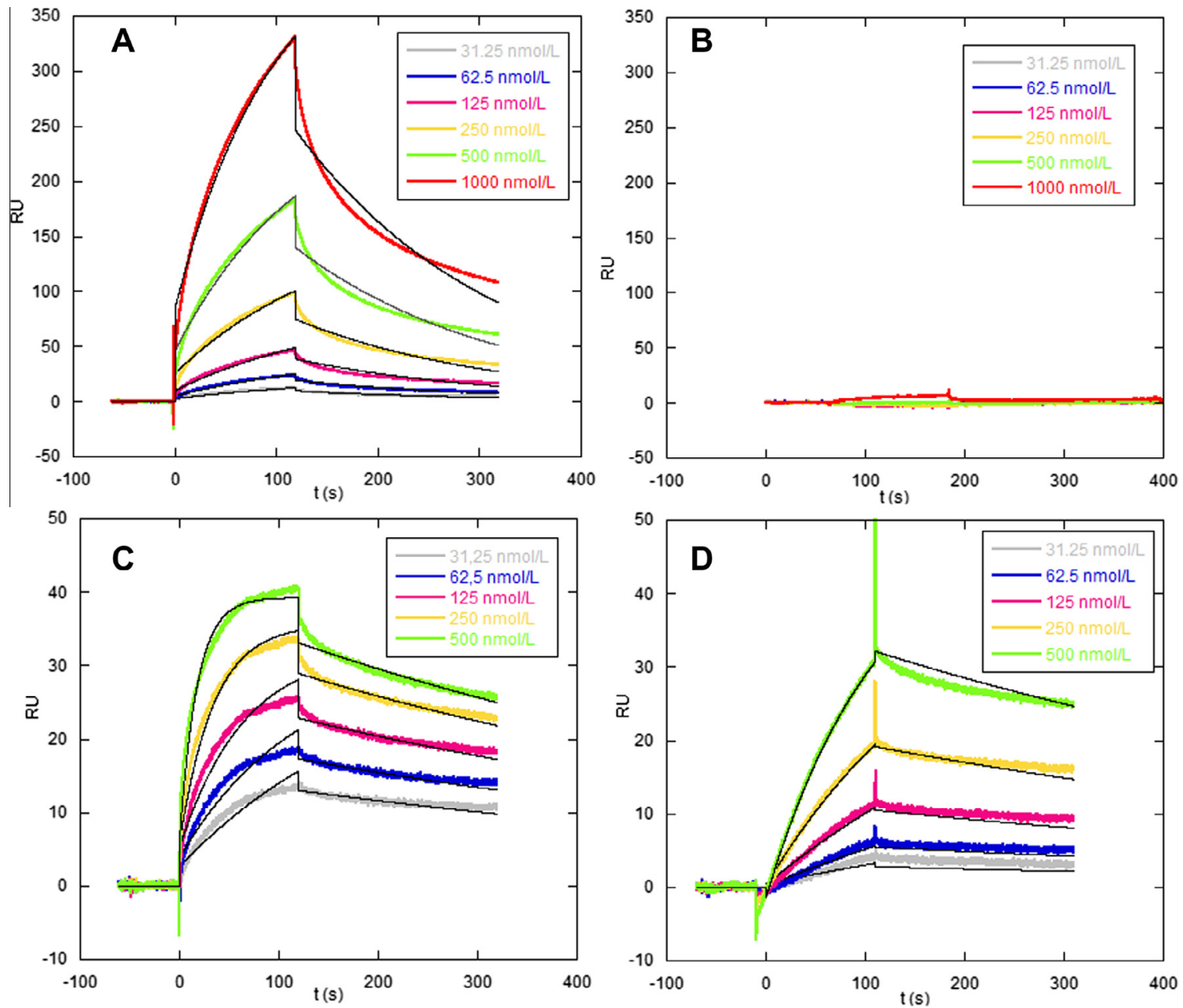

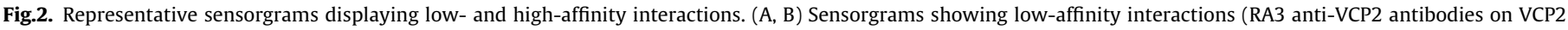

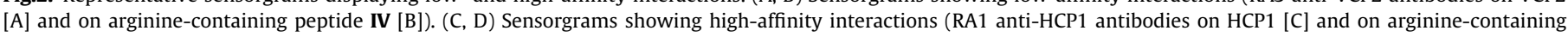
peptide $\mathbf{V}[D])$. RU, resonance units.

Table 3

Affinity constant $K_{\mathrm{D}}$ calculated with the $1: 1$ binding model for interactions between purified antibody fractions and the peptide used for their purification and the corresponding non-citrullinated sequence.

\begin{tabular}{|c|c|c|}
\hline & $K_{\mathrm{D}}(\mathrm{mol} / \mathrm{L})$ & \\
\hline & VCP2 & VArgP2 \\
\hline RA1 anti-VCP2 & $6.68 \pm 0.12 \times 10^{-7}$ & No binding \\
\hline RA2 anti-VCP2 & $1.45 \pm 0.04 \times 10^{-6}$ & No binding \\
\hline RA3 anti-VCP2 & $9.58 \pm 0.28 \times 10^{-7}$ & No binding \\
\hline RA4 anti-VCP2 & $5.15 \pm 0.26 \times 10^{-7}$ & $3.39 \pm 0.02 \times 10^{-7}$ \\
\hline \multirow[t]{3}{*}{ RA5 anti-VCP2 } & $9.92 \pm 0.25 \times 10^{-7}$ & No binding \\
\hline & \multicolumn{2}{|l|}{$\mathrm{K}_{\mathrm{D}}(\mathrm{mol} / \mathrm{L})$} \\
\hline & $\mathrm{HCP} 1$ & HArgP1 \\
\hline RA1 anti-HCP1 & $2.51 \pm 0.03 \times 10^{-8}$ & $1.80 \pm 0.04 \times 10^{-7}$ \\
\hline RA2 anti-HCP1 & $1.61 \pm 0.04 \times 10^{-8}$ & $6.95 \pm 0.21 \times 10^{-9}$ \\
\hline RA3 anti-HCP1 & $4.28 \pm 0.12 \times 10^{-8}$ & Low binding \\
\hline RA4 anti-HCP1 & $4.94 \pm 0.17 \times 10^{-8}$ & $1.76 \pm 0.12 \times 10^{-5}$ \\
\hline RA5 anti-HCP1 & $1.49 \pm 0.02 \times 10^{-8}$ & No binding \\
\hline
\end{tabular}

and fibrin [20] has demonstrated that, despite the existence of major epitopes recognized by many sera, RA patients display many different reactivity profiles [18]. Comparing the results obtained testing a panel of sera on VCP2, VCP1, and CCP, we found that, despite an overall high correlation, some sera react with only one or two antigens, thereby suggesting that different non-overlapping epitopes may be targeted by ACPAs [6].

By means of liquid phase inhibition assays, evidence for the existence of both cross-reactive and non-cross-reactive ACPAs was obtained with fibrin-derived [21], filaggrin-derived [19], and Epstein-Barr nuclear antigen (EBNA)-derived peptides [6]. The biosensor analysis reported in the current study similarly indicates that anti-peptide antibodies from sera reactive with all three citrullinated peptides are widely cross-reactive. In fact, antibodies isolated by affinity chromatography on any of the peptides also react with the other two citrullinated antigens. In this respect, it is of interest that purified anti-VCP1 and anti-VCP2 antibodies have a higher apparent affinity for HCP1 than for VCP1 and VCP2.

Analyzing the binding to non-citrullinated sequences, we found that in most cases the antibodies are specific for citrulline-containing peptides and bind with a much lower apparent affinity the arginine-containing ones. This result represents additional evidence for the exquisite specificity of antibodies from RA patients for citrullinated sequences. The only exception is represented by the antibodies specific for the citrullinated histone peptide, 
obtained from one RA patient, that bind with a higher apparent affinity than the arginine-containing sequence. It is likely that these antibodies are specific for the C-terminal portion of the peptide, which is devoid of citrullines, and thus represent an example of anti-histone antibodies detectable in RA sera [22].

According to the results of the current study, ACPAs are heterogeneous not only in terms of specificity but also in terms of apparent affinity. ACPAs specific for the EBNA-derived peptides VCP1 and VCP2 are in fact characterized by a lower apparent affinity than those binding the histone peptide. VCP1 and VCP2 contain a glycine-citrulline stretch that represents an epitope shared by the two sequences and targeted by antibodies present in RA sera; a second non-overlapping epitope is located in the N-terminal portion of VCP2 [6]. Thus, the structural similarity of VCP1 and VCP2 may explain a similar affinity of antibodies that bind the two peptides. HCP1, on the contrary, is structurally different; it does not contain stretches of citrullines flanked by small/neutral amino acids and, despite the substitution of arginine with citrulline, it has a strong positive charge due to several lysine residues.

Previous data on ACPA affinity have been obtained by elution ELISA, using citrullinated proteins such as fibrinogen and vimentin, or CCP on the solid phase [13]. Citrullinated proteins as well as CCP, which is a mixture of synthetic peptides, bear multiple epitopes recognized by RA sera and, thus, allow an "average" evaluation of affinity. These tools detected no differences in affinity among antibodies binding CCP, citrullinated fibrinogen, or citrullinated vimentin [13]. On the contrary, using synthetic peptides that bear a limited number of epitopes and allow analyzing an oligoclonal population of antibodies, a spectrum of avidities was detected. At variance with previous studies, we analyzed the apparent affinity of ACPAs for citrullinated peptides derived from exogenous antigens (VCP1 and VCP2) or autoantigens (HCP1) and found that the apparent affinity for HCP1 is higher also when antibody affinity purified on VCP1 and VCP2 is tested. These results may suggest that antibodies initially elicited by an exogenous antigen (EBV derived) are then "selected" and expanded by autoantigens (e.g., histones).

In conclusion, we evaluated by SPR the apparent affinity of ACPAs, purified from RA patients' sera, to peptides VCP1, VCP2, and HCP1, observing high cross-reactivity and heterogeneity. Calculated affinity constants for ACPA-peptide interactions presented sensible differences (1-fold in $K_{\mathrm{D}}$ values) between viral peptides VCP1-VCP2 and histone peptide HCP1. These findings have potential clinical relevance because the peptides analyzed are employed in solid phase assays for the diagnosis of RA.

\section{Acknowledgment}

Ente Cassa Risparmio di Firenze is gratefully acknowledged for the financial support to PeptLab@Unifi.

\section{References}

[1] G.J. Pruijn, A. Wiik, W.J. van Venrooij, The use of citrullinated peptides and proteins for the diagnosis of rheumatoid arthritis, Arthritis Res. Ther. 12 (2010) 203.

[2] D. Aletaha, T. Neogi, A.J. Silman, J. Funovits, D.T. Felson, C.O. Bingham, N.S. Birnbaum, G.R. Burmester, V.P. Bykerk, M.D. Cohen, B. Combe, K.H. Costenbader, M. Dougados, P. Emery, G. Ferraccioli, J.M. Hazes, K. Hobbs, T.W. Huizinga, A. Kavanaugh, J. Kay, T.K. Kvien, T. Laing, P. Mease, H.A. Ménard, L.W. Moreland, R.L. Naden, T. Pincus, J.S. Smolen, E. Stanislawska-Biernat, D. Symmons, P.P. Tak, K.S. Upchurch, J. Vencovsky, F. Wolfe, G. Hawker, Rheumatoid arthritis classification criteria: An American College of
Rheumatology/European League against Rheumatism collaborative initiative, Ann. Rheum. Dis. 69 (2010) (2010) 1580-1588.

[3] H. Uysal, K.S. Nandakumar, C. Kessel, S. Haag, S. Carlsen, H. Burkhardt, R. Holmdahl, Antibodies to citrullinated proteins: molecular interactions and arthritogenicity, Immunol. Rev. 233 (2010) 9-33.

[4] F. Pratesi, I. Dioni, C. Tommasi, M.C. Alcaro, I. Paolini, F. Barbetti, F. Boscaro, F. Panza, I. Puxeddu, P. Rovero, P. Migliorini, Antibodies from patients with rheumatoid arthritis target citrullinated histone 4 contained in neutrophils extracellular traps, Ann. Rheum. Dis. 73 (2014) 1414-1422.

[5] F. Pratesi, C. Tommasi, C. Anzilotti, D. Chimenti, P. Migliorini, Deiminated Epstein-Barr virus nuclear antigen 1 is a target of anti-citrullinated protein antibodies in rheumatoid arthritis, Arthritis Rheum. 54 (2006) 733-741.

[6] F. Pratesi, C. Tommasi, C. Anzilotti, I. Puxeddu, E. Sardano, G. Di Colo, P. Migliorini, Antibodies to a new viral citrullinated peptide, VCP2: fine specificity and correlation with anti-cyclic citrullinated peptide (CCP) and anti-VCP1 antibodies, Clin. Exp. Immunol. 164 (2011) 337-345.

[7] M.A. van Boekel, E.R. Vossenaar, F.H. van den Hoogen, W.J. van Venrooij, Autoantibody systems in rheumatoid arthritis: specificity, sensitivity, and diagnostic value, Arthritis Res. 4 (2002) 87-93.

[8] C. Clavel, L. Nogueira, L. Laurent, C. Iobagiu, C. Vincent, M. Sebbag, G. Serre, Induction of macrophage secretion of tumor necrosis factor through $\mathrm{Fc}$ receptor IIa engagement by rheumatoid arthritis-specific autoantibodies to citrullinated proteins complexed with fibrinogen, Arthritis Rheum. 58 (2008) 678-688.

[9] M.C. Lu, N.S. Lai, H.C. Yu, H.B. Huang, S.C. Hsieh, C.L. Yu, Anti-citrullinated protein antibodies bind surface-expressed citrullinated Grp78 on monocyte/ macrophages and stimulate tumor necrosis factor production, Arthritis Rheum. 62 (2010) 1213-1223.

[10] T. Dougan, J.B. Levy, A. Salama, A.J. George, C.D. Pusey, Characterization of autoantibodies from patients with Goodpasture's disease using a resonant mirror biosensor, Clin. Exp. Immunol. 128 (2002) 555-561.

[11] A. Rutgers, K.E. Meyers, G. Canziani, R. Kalluri, J. Lin, M.P. Madaio, High affinity of anti-GBM antibodies from Goodpasture and transplanted Alport patients to 3(IV)NC1 collagen, Kidney Int. 58 (2000) 115-122.

[12] P. Achenbach, K. Koczwara, A. Knopff, H. Naserke, A.G. Ziegler, E. Bonifacio, Mature high-affinity immune responses to (pro)insulin anticipate the autoimmune cascade that leads to type 1 diabetes, J. Clin. Invest. 114 (2004) 589-597.

[13] P. Suwannalai, H.U. Scherer, D. van der Woude, A. Ioan-Facsinay, C.M. Jol-van der Zijde, M.J. van Tol, J.W. Drijfhout, T.W. Huizinga, R.E. Toes, L.A. Trouw, Anticitrullinated protein antibodies have a low avidity compared with antibodies against recall antigens, Ann. Rheum. Dis. 70 (2011) 373-379.

[14] P. Suwannalai, L.A. van de Stadt, H. Radner, G. Steiner, H.S. El-Gabalawy, C.M. Zijde, M.J. van Tol, D. van Schaardenburg, T.W. Huizinga, R.E. Toes, L.A. Trouw, Avidity maturation of anti-citrullinated protein antibodies in rheumatoid arthritis, Arthritis Rheum. 64 (2012) 1323-1328.

[15] A.M. Lokate, J.B. Beusink, G.A. Besselink, G.J. Pruijn, R.B. Schasfoort, Biomolecular interaction monitoring of autoantibodies by scanning surface plasmon resonance microarray imaging, J. Am. Chem. Soc. 129 (2007) 1401314018.

[16] F. Real-Fernández, I. Passalacqua, E. Peroni, M. Chelli, F. Lolli, A.M. Papini, P. Rovero, Glycopeptide-based antibody detection in multiple sclerosis by surface plasmon resonance, Sensors (Basel) 12 (2012) 5596-5607.

[17] K. Amara, J. Steen, F. Murray, H. Morbach, B.M. Fernandez-Rodriguez, V. Joshua, M. Engström, O. Snir, L. Israelsson, A.I. Catrina, H. Wardemann, D. Corti, E Meffre, L. Klareskog, V. Malmström, Monoclonal IgG antibodies generated from joint-derived $B$ cells of RA patients have a strong bias toward citrullinated autoantigen recognition, J. Exp. Med. 210 (2013) 445-455.

[18] J.J. van Beers, A. Willemze, J.J. Jansen, G.H. Engbers, M. Salden, J. Raats, J.W. Drijfhout, A.H. van der Helm-van Mil, R.E. Toes, G.J. Pruijn, ACPA finespecificity profiles in early rheumatoid arthritis patients do not correlate with clinical features at baseline or with disease progression, Arthritis Res. Ther. 15 (2013) R140.

[19] G.A. Schellekens, B.A. de Jong, F.H. van den Hoogen, L.B. van de Putte, W.J. van Venrooij. Citrulline is an essential constituent of antigenic determinants recognized by rheumatoid arthritis-specific autoantibodies, J. Clin. Invest. 101 (1998) 273-281.

[20] M. Sebbag, N. Moinard, I. Auger, C. Clavel, J. Arnaud, L. Nogueira, J. Roudier, G. Serre, Epitopes of human fibrin recognized by the rheumatoid arthritis-specific autoantibodies to citrullinated proteins, Eur. J. Immunol. 36 (2006) 22502263.

[21] O. Snir, M. Widhe, C. von Spee, J. Lindberg, L. Padyukov, K. Lundberg, A. Engström, P.J. Venables, J. Lundeberg, R. Holmdahl, L. Klareskog, V. Malmström, Multiple antibody reactivities to citrullinated antigens in sera from patients with rheumatoid arthritis: association with HLA-DRB1 alleles, Ann. Rheum. Dis. 68 (2009) 736-743.

[22] Y. Allanore, J. Sellam, F. Batteux, C. Job Deslandre, B. Weill, A. Kahan, Induction of autoantibodies in refractory rheumatoid arthritis treated by infliximab, Clin. Exp. Rheumatol. 22 (2004) 756-758. 